\title{
Chapter 8 \\ Empowering University Educators \\ for Contemporary Open and Networked \\ Teaching
}

\author{
Fabio Nascimbeni
}

\begin{abstract}
The chapter explores the competences that university educators should master in our increasingly digital, open and connected societies in order to fill their role effectively and responsibly. Starting from a brief analysis of the concepts of collaborative learning and open education, we analyse three teachers' competencies frameworks, focusing on the digital, collaboration and openness aspects of contemporary teaching. We conclude that educators should not build radically new competences but should rather update their competences in line with emerging needs. Also, we notice that some additional competence areas should be developed by educators, if we want them to be able to bridge the work of students in formal and informal settings. We propose six competences areas in this sense: personal data management, capacity to leverage the open web, intercultural digital dialogues, critical view on media, digital ethical issues, accessibility. These areas are becoming increasingly important for educators to be able to critically engage learners in the core issues of our digital, networked and open societies, guiding them-in open and collaborative ways - towards solutions to the newly emerging problems of our times.
\end{abstract}

Keywords Open and networked teaching $\cdot$ Higher education $\cdot$ Teachers training • Collaborative learning $\cdot$ Teaching innovation $\cdot$ Open education

\subsection{Introduction: A New Role for Educators in Contemporary Societies}

We are living in an increasingly open and participatory society, characterised by developments such as a growing importance of informal learning, new understandings of intellectual property, mixed modes of cultural expressions and a more proactive conception of citizenship (Jenkins, Ito, \& boyd, 2015). The impact of these developments on the way people learn is twofold. On the one hand, the pervasive and seamless presence of Information and Communication Technology (ICT) has

\footnotetext{
F. Nascimbeni $(\bowtie)$

Research Institute for Innovation \& Technology in Education (UNIR iTED),

Universidad Internacional de La Rioja (UNIR), Logroño, La Rioja, Spain

e-mail: fabio.nascimbeni@unir.net

(C) The Author(s) 2020

D. Burgos (ed.), Radical Solutions and Open Science, Lecture Notes

in Educational Technology, https://doi.org/10.1007/978-981-15-4276-3_8
} 
made a number of processes typical of the learning value chain more efficient, thanks to approaches such as mobile learning, learning analytics or personalised learning (Bates, 2015). On the other hand, new developments such as the emergence of Open Educational Resources (OER) or the use of social networks for teaching are fostering pedagogic innovation, moving away from traditional lecture-based dynamics towards open and networked teaching practices (Kyndt et al., 2013; Van Leeuwen, Janssen, Erkens, \& Brekelmans, 2013).

In order for universities to adapt to these changes and to be able to maintain their relevance within society, many aspects of higher education need to be restructured (Sledge \& Dovey Fishman, 2014), starting with the role of educators (Pearce, Weller, Scanlon, \& Kinsley, 2010). "The three key elements of digital, networked and open converge most significantly around the production, pedagogy and delivery of education" (Weller, 2012, p. 85). The role of educators, traditionally considered as the experts tasked with communicating the necessary bodies of knowledge to students, is being questioned by educational researchers, who tend to increasingly define educators as co-travellers, mediators or facilitators. Connectivism emerged as a new educational theory supporting these claims. This theory considers that the spread of ICT and the deriving open and networked pedagogic approaches are challenging traditional schemes within education systems, and, in particular, the idea that educators are the only ones entitled to produce and deliver knowledge (Siemens, 2004; Downes, 2012; Rivoltella \& Rossi, 2012). "Since the distributed and networked structure of knowledge in the digital age challenges the traditional view of education delivered within the borders of school, strict time periods and content, the role of the teacher has been redefined in the context of the connectivist paradigm to include networked learning environments" (Ozturk, 2015, p. 6).

\subsection{Setting the Target: Collaborative and Open Teaching}

In order to better understand the new role of university educators as well as to start defining the competences that they should master to fill their function effectively and responsibly, we will start from two educational approaches: collaborative learning and open education. These approaches have been existing since human beings started to reflect on teaching and learning, and are increasingly gaining ground in contemporary open and networked societies. Collaborative learning is about learners working together to understand concepts, to develop projects, to solve problems and ultimately to create knowledge. If properly managed, collaborative learning has the potential to foster the strengths of individual students while building fundamental skills such as teamwork, problem-solving and empathy (Kyndt et al., 2013). Within this approach, peer-to-peer learning is particularly important, since it engages learners in the same working processes providing them with opportunities to teach and be taught by one another (Williams et al., 2011). Open education deals with opening up the different components of the educational process (Weller, 2014), making sure that all necessary barriers to learning are removed. The change brought by open education 
touches upon all aspects of educators' work: learning design, for example, through sharing course design ideas with fellow teachers and with students, teaching content, by using and allowing the reuse of OER, and pedagogical approaches, for instance, by fostering participation of non-enrolled students and of other stakeholders in the learning process (Nascimbeni \& Burgos, 2016).

While in formal educational contexts the change process towards open and networked learning is happening at a relatively slow pace (OECD, 2016), in informal learning settings collaboration and openness are often the norm. Think, for example, of a person openly sharing a video on a specific theme (from music to carpentry to physics) to explain a concept to a community. This simple act, translated into formal learning settings such as within a university course, is fully in line with Conole's five principles of open learning: collaboration and sharing of information, connected communication about learning and teaching, collectivity to grow knowledge and resources, critique for the promotion of scholarship and serendipitous innovation (Conole, 2013). Successful collaborative and open learning is indeed the key to build active learning environments, encouraging students to give and receive feedback and to evaluate each other's learning, and can have a tremendous impact on the development of twenty-first-century skills such as intercultural communication and critical thinking (Dede, 2010).

\subsection{Competence Frameworks for Open and Networked Teaching}

Adapting the work of Stacey (2013) and Reynolds (2015), we can ascertain three key characteristics that open and networked educators should have. First, they should nurture learners' connections and dialogues for the purpose of sharing ideas and solving problems, considering their classroom as a learning network where each link represents a possibility for new learning. Second, educators should be able to work in the open, engaging learners in a collaborative process of knowledge co-creation and open sharing, instead of just letting them use a pre-defined set of learning resources. Third, they should consider learners as autonomous agents within the learning process, allowing them to operate independently and learn at their own pace, in their own direction, and using their own connections.

The transition process of educators along these lines entails not only changing the way teachers design their courses, license their materials, support knowledge creation among students, but also supporting a reflection on their professional identity, and is therefore an extremely challenging process. The introduction of collaborative and open practices brings in fact a major cultural shift within educators' self-perception, related to the need of rethinking and reshaping the roles played by teachers and students within the learning process and the underpinning knowledge production process (Rivoltella \& Rossi, 2012). This process is made more complex by the fact that in general terms educators do not feel competent in implementing innovative 
and collaborative approaches in their teaching (Gillies \& Boyle, 2010; Ruys, Van Keer, \& Aelterman, 2011).

Given the complexity of the task, a first important step is to define which competences should be mastered by educators to be able to meaningfully and responsibly teach through open and networked practices. A good place to start looking for these competences are the existing competence frameworks that aim to define the competences of educators in contemporary societies. An important recent development in this domain is the DigCompEdu framework by the Joint Research Centre of the European Commission, that aims to inspire digital literacy initiatives in European countries targeted to educators (Kluzer \& Pujol, 2018) (Fig. 8.1).

DigCompEdu is advocating for a rather holistic understanding of digital literacy, that considers the needed digital competences of twenty-first-century educators, in the centre of the above figure, together with their professional engagement activities, on the left side, and with the impact that teachers can have on their learner's digital literacy, on the right side (Nascimbeni, 2018). The framework operationalises this approach through six competencies areas: (1) work effectively in an ICT-rich professional environment, (2) find, create and share digital resources, (3) effectively use digital tools for teaching and learning, (4) enhance learning assessment through ICT, (5) empower learners and foster learners-centred strategies through the use of digital tools and (6) create digital literacy among learners, in terms of active citizenship and media literacy. These areas are then detailed along 23 competences, with exhaustive proficiency descriptors. By looking at the way these competences are described, we find that collaboration (among teachers, with students and with other stakeholders) inspires the whole framework, and that openness is definitely present, both in terms of use of OER and of stakeholders' engagement and collaboration. The DigCompEdu framework does indeed advocate for a change in the role of teachers, by introducing

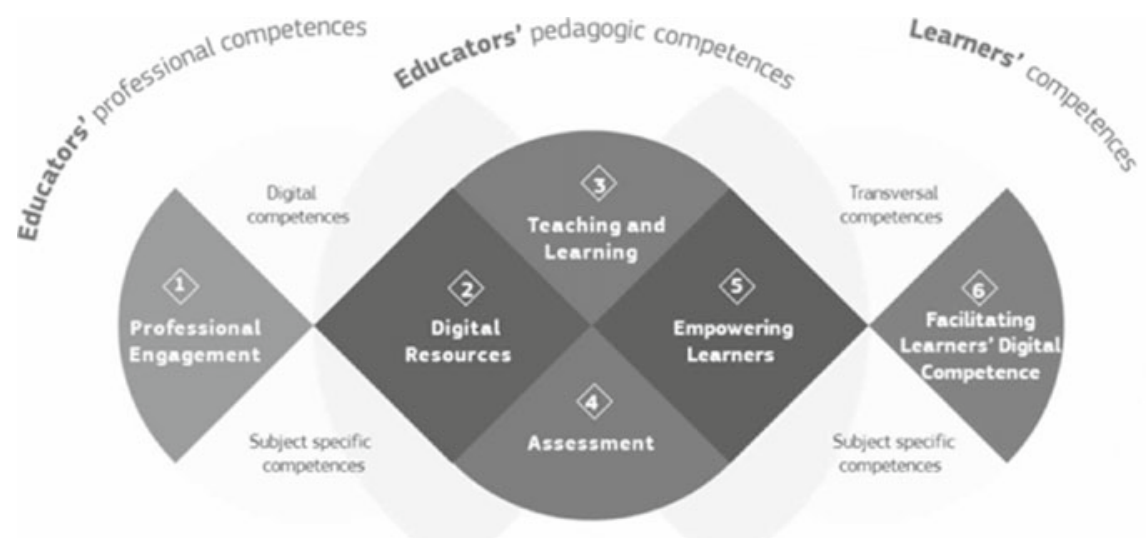

Fig. 8.1 The DigComp Edu framework (Kluzer \& Priego, 2018) 
meta-cognitive and self-development teachers' competences, getting them ready for open and networked learning settings (Loeckx, 2016).

To complement the DigCompEdu framework, that addresses collaboration and openness through the lens of digital literacy, it is important to consider also educators competencies frameworks that target specifically collaborative learning and open education.

An attempt to capture the competencies categories that educators would need to acquire to successfully implement collaborative learning in the classroom has been done with the Implementing Collaborative Learning in the Classroom (ICLC) framework (Kaendler, Wiedmann, \& Rummel, 2015). The proposed competences areas identified within ICLC are: planning, connected to the course preparation phase; monitoring, supporting and consolidating, connected to the course interactive phase; and reflecting, for the post-course phase. These should be accompanied by subjectspecific knowledge and by teachers' beliefs and attitudes, two important elements that influence the selected collaborative learning strategies (Fig. 8.2).

The most interesting feature of the framework is that it stresses the fact that - in order to successfully adopt collaborative learning practices-educators do not need to acquire new competences, but they rather require to adapt their teaching strategies to collaborative learning settings. The proposed competences areas are indeed typical of teaching cycles and are declined in such a way to support collaborative learning. The pre-active phase deals with lessons preparation and with setting up the collaborative learning system before students start working in groups. In the inter-active phase, educators support students to find solutions to the problem they are working on and to facilitate review of the work by other students. Finally, the post-active phase takes deals with the capacity of facilitating learners' reflection on the previous phases.

In the area of open education, the eight attributes presented in Fig. 8.3 (Hegarty, 2015) do represent quite well what are the key competences that educators needs to master in order to work openly with their students.

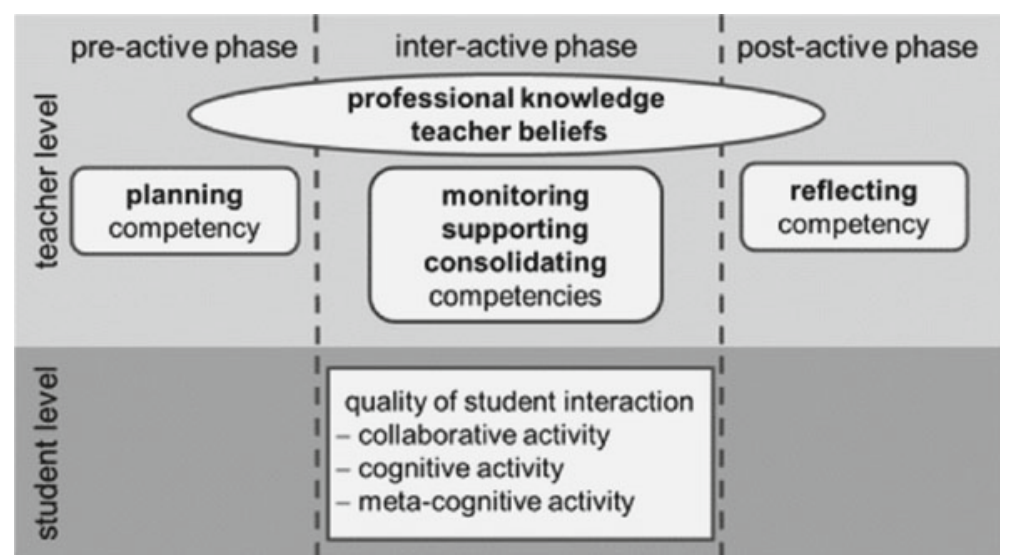

Fig. 8.2 The ICLC framework (Kaendler et al., 2015) 


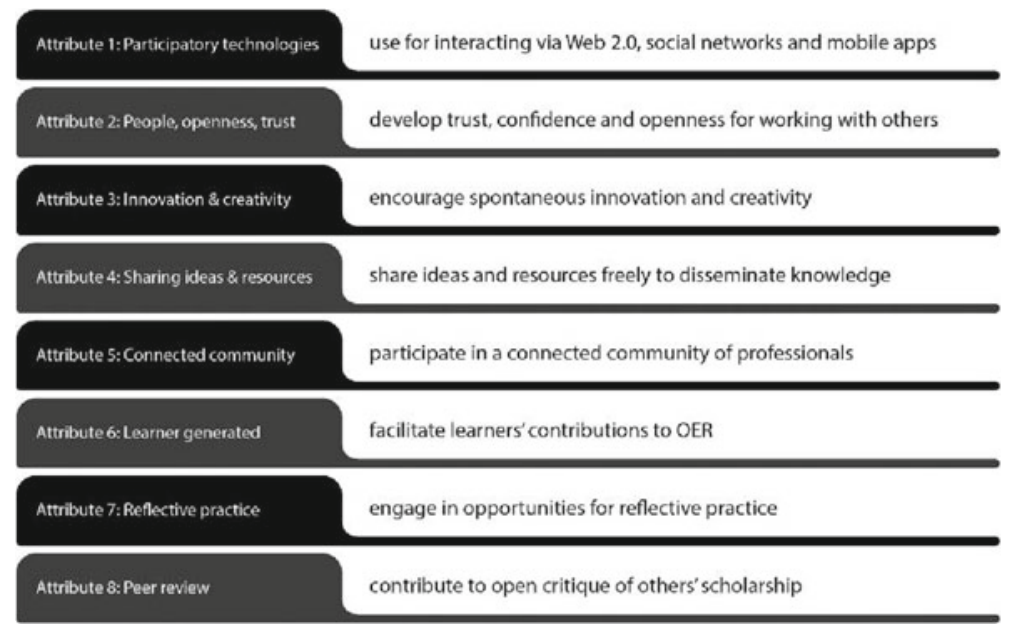

Fig. 8.3 Eight attributes of open pedagogy (Hegarty, 2015)

Also in this case, the majority of competences are actually open declinations of typical educators' competences. As noted by a recent JRC report, academics need to start from their teaching practices in order to find ways in which they can share and collaborate openly, and this must be accompanied not so much by new competencies but rather by a mindset shift (Inamorato dos Santos, 2019). It must be noted that, as given openness is strongly connected with personal attitudes and preferences (Cronin, 2017), it is almost impossible to split the components of open education into clearly distinct dimensions. The components of the eight dimensions indeed overlap in many ways and are all part of a new way of teaching, that fosters trust, sharing, collaboration, connectedness, peer interaction and review. As we have seen before when analysing the competences needed to support collaborative learning, also in the realm of openness it is fundamental to let students be in control of their work, for example, by letting them chose the open licenses they prefer or what parts of their work they want to publish openly (Ward, 2017).

\subsection{Suggested New Competency Areas for Open and Networked Educators}

Our analysis of the three competence frameworks presented above concludes that educators should not build radically new competences but should rather update their competences in terms of collaborative learning and open education, at least as long as we stay within the formal education realm. Nevertheless, one key capacity of contemporary educators - not only in higher education - is to be able to meaningfully bridge formal and informal learning, connecting the work that happens in the 
classroom with the many knowledge-rich activities that take place outside learning institutions. In this perspective, some additional competences should be acquired by teachers to actively manage the knowledge they produce and to make use of knowledge produced by their students, in a collaborative, engaging and open way.

We propose six competences areas that should be explored to align the capacities of educators with the needs of contemporary open and networked societies, at the same time bridging formal and informal learning (Fig. 8.4).

First, personal data management. In a data-driven society, being able to understand the issues and criticalities connected to the use of personal data is fundamental. This has to do with comprehending the terms of use of online platforms as well as with behaving in line with legal and technological developments, but also with using learners' data properly when applying learning analytics techniques (Slade and Prinsloo, 2013). This is particularly important given the raise of online business models, also within educational settings, that involve tracking and profiling of users, whose data can potentially be misused in many ways (O'Neil, 2016). A possible source to define the detailed competences that should be included in this area is the My Data model, a rather advanced approach that aims to move from the current organization centric models to human centric systems where personal data are treated as a resource that the individuals can easily access and decide upon (Poikola, Kuikkaniemi, \& Honko, 2014).

Second, the capacity to leverage the open web. In a society where openly sharing knowledge is becoming in many cases the norm, a fundamental component of educators' literacy should be the capacity to both share the knowledge they produce and to make use of knowledge produced by others in a responsible, transparent and traceable way (Villar, 2019). Learning how to teach through open communities and with open and networked practices implies both a set of technical skills, related, for example, to copyright understanding, and a fundamental change in daily practices of course design, content production, teaching and assessment (Nascimbeni \& Burgos, 2016). By relying on the open web, educators should be able to work through open

Fig. 8.4 Six competence areas for open and networked teaching

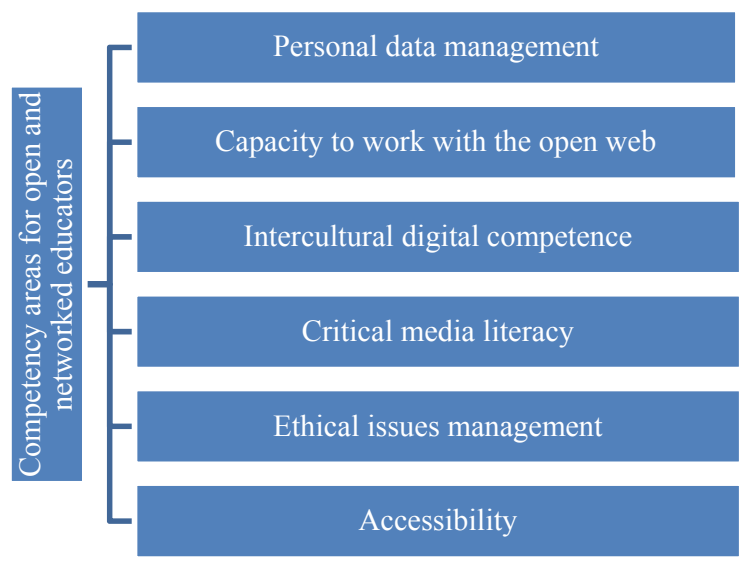


and connected online identities, meaning that they should adopt a transparent and consistent attitude in online spaces related to their teaching work (Ross, Sinclair, Knox, Bayne, \& Macleod, 2014) and should rely on social networks to enrich their teaching by setting up and nurturing their personal learning network (Tour, 2017).

With the ability to engage in intercultural digital dialogues we mean that educators should use digital technologies to move from a reactive and defensive position with respect to the increased multiculturality of our societies - and of our students' cohorts - towards an active approach able to add value to learning experiences thanks to the existence of multiple cultural perspectives. Apart from developing intercultural communication skills, engaging in intercultural digital dialogues bears the capacity to move across diverse online communities, grasping and following alternative norms and respecting multiple perspectives. This in turn can influence the possibility of learners with different backgrounds to identify with and relate to teaching resources, avoiding biases and stereotypes (Elder, 2019).

Fourth, having a critical view on media means being able to deconstruct, question and challenge online and offline media content. In a world where $40 \%$ of young people seem to prefer to get their news from social media (Common Sense Media, 2018), educators must be able to support students in understanding the implications of the current cognitive war (Trinchero, 2018), including the difference between real and fake news. In more general terms, they shall guide students on how to consume, understand and create media that corresponds to fact-checking standards. Already in 2008, before the massive advent of social media, UNESCO had identified five broad competencies for media and information literacy: understanding, critical thinking, creativity, cultural awareness and citizenship (UNESCO, 2008). Since then, a number of efforts have tried to detail what being media literate today should mean (see e.g. Richardson, Milovidov, \& Schmalzried, 2017), but to our knowledge educators' competences have not yet been targeted deeply enough by the media literacy movements.

Fifth, the capacity to deal with digital ethical issues. Already recognised as one of the three fundamental dimension of teachers' digital literacy more than a decade ago (Calvani et al., 2008), ethical issues have been gaining importance in the era of social media. Educators shall know when and at what conditions information can be shared, or whether or not they can use openly available knowledge, or how to deal with issues such as Artificial Intelligence or the scarcity of learners' attention (Farrow 2016). The problem is that most of these questions lie in grey areas where solutions are being debated at the moment, and are connected with the need to be able to apply traditional ethical frameworks to problems that are emerging in the digital world.

Sixth, educators should be able to deal with accessibility issues. First, they should be aware of technical web accessibility issues, so to allow students with access limitations to understand, navigate and contribute to the web. Second, they should be able to make their courses more accessible to all student categories, including disabled students. One way to do this is to follow the Universal Design for Learning (UDL) framework, which provides multiple ways of engaging with a course content, for example, representing ideas from different angles and in different media 
types, providing support for students to express their understanding of concepts in different ways, or allowing students to engage through a variety of different activities depending on their capacity (Rose \& Meyer, 2007).

Two considerations must be made about these areas of competency. First, this does not want to be an exhaustive list, since new important competences are continuously being codified. To make an example, computational thinking could probably be added to the list, given its role in facilitating the understanding of how and why certain elements of our digital world are framed in specific ways, including the way big data and related algorithms work. Second, these competencies, some of which were not even grouped as such just a few years ago, dynamically evolve over time, influencing and being influenced by technological and societal developments. To make an example, being capable of collaborating online some 15 years ago, before the boom of social media, meant a completely different thing with respect to being able to collaborate online today. These competences are therefore inherently difficult to be documented and framed in a capacity building process, and because of this they should be developed through experiential approaches, making sure that enough attention is put on all the sociocultural nuances of what it means to live-and teach-in contemporary open and collaborative societies.

\subsection{Conclusions}

Contemporary educators must be able to prepare students to be active and responsible citizens in increasingly knowledge-based and knowledge-sharing society, managing their emerging collective intelligence dynamics in an open and transparent way (Recker, Yuan \& Ye, 2014). In order to do so, they need to be capable of engaging learners in digital dialogues based on shared ethical, multicultural and equity strategies and to foster the role of students as knowledge producers and not just as consumers (Alexander, Adams Becker, \& Cummins, 2016). Such an engagement capacity would also help bridging formal and informal learning settings, since research shows that students are not always comfortable with collaborative teaching approaches within formal learning settings, despite their daily use of social networks (Schleicher, 2014).

If we want our students to develop a curios and critical mindset and to become independent, resilient and self-regulated citizens, we need educators that can critically discuss with them the core issues of our increasingly digital, networked and open societies, guiding them towards solutions to the newly emerging problems of our times. For this to happen, we must make sure that educators develop the capacity to adapt their experience to open and networked settings, at the same time acquiring a set of new competences. Only by building on teachers experience and at the same time enriching this with new skills, educators can transform into actors able both to teach competently in digital, open and networked settings and to co-shape with their learners existing practices in an active ad critical way. 


\section{References}

Alexander, B., Adams Becker, S., \& Cummins, M. (2016). Digital literacy: An NMC horizon project strategic brief (Vol. 3.3). New Media Consortium.

Bates, T. (2015). Teaching in the digital age. BC Open Textbooks.

Calvani, A., Cartelli, A., Fini, A. \& Ranieri, M. (2008). Models and instruments for assessing: Digital competence at school. Journal of e-Learning and Knowledge Society, 4(3), 183-193. Italian e-Learning Association.

Common Sense Media. (2018). The common sense census: Media use by kids age zero to eight 2017. Retrieved from https://www.commonsensemedia.org/research/the-common-sense-censusmedia-use-by-kids-age-zero-to-eight-2017.

Conole, G. (2013). Designing for learning in an open world. New York: Springer.

Cronin, C. (2017). Openness and Praxis: Exploring the use of open educational practices in higher education. The International Review of Research in Open and Distributed Learning, 18(5).

Dede, C. (2010). Comparing frameworks for 21 st century skills. In J. Bellance \& R. Brandt (Eds.), 21st century skills: Rethinking how students learn (pp. 51-76). Bloomington: Solution Tree.

Downes, S. (2012). Connectivism and connective knowledge: Essays on meaning and learning networks. Ottawa: National Research Council Canada.

Elder, A. K. (2019). The OER starter kit. Ames: Iowa State University Digital Press.

Farrow, R. (2016). A framework for the ethics of open education. Open Praxis, 8(2), 93-109.

Gillies, R. M., \& Boyle, M. (2010). Teachers' reflections on cooperative learning: Issues of implementation. Teaching and Teacher Education, 26, 933-940.

Hegarty, B. (2015). Attributes of Open pedagogy: A model for using open educational resources. Educational Technology.

Inamorato dos Santos, A. (2019). Practical guidelines on open education for academics: Modernising higher education via open educational practices (based on the OpenEdu Framework), EUR 29672 EN, Publications Office of the European Union, Luxembourg, 2019, ISBN 978-92-76-00194-2, https://doi.org/10.2760/55923, JRC115663.

Jenkins, H., Ito, M. \& Boyd, D. (2015). Participatory culture in a networked Era: A conversation on youth, learning, commerce, and politics. Cambridge: Polity Press.

Kaendler, C., Wiedmann, M., Rummel, N., et al. (2015). Teacher competencies for the implementation of collaborative learning in the classroom: A framework and research review. Education Psychology Review, 27, 505.

Kluzer, S., \& Pujol, P. L. (2018). DigComp into action-Get inspired, make it happen. Luxembourg: Publications Office of the European Union.

Kyndt, E., Raes, E., Lismont, B., Timmers, F., Cascallar, E., \& Dochy, F. (2013). A meta-analysis of the effects of face-to-face cooperative learning. Do recent studies falsify or verify earlier findings? Educational Research Review, 10, 133-149.

Loeckx, J. (2016). Blurring boundaries in education: Context and impact of MOOCs. The International Review Of Research In Open And Distributed Learning, 17(3).

Nascimbeni, F. (2018). Rethinking digital literacy for teachers in open and participatory societies. International Journal of Digital Literacy and Digital Competence (IJDLDC), 9(3), 1-11.

Nascimbeni, F. \& Burgos, D. (2016). In search for the open educator: Proposal of a definition and a framework to increase openness adoption among University Educators. The International Review of Research in Open and Distributed Learning, 17(6).

OECD. (2016). Innovating education and educating for innovation: The power of digital technologies and skills. Paris: OECD.

O'Neil, C. (2016). Weapons of math destruction: How big data increases inequality and threatens democracy. New York: Crown.

Ozturk, H. T. (2015). Examining value change in MOOCs in the scope of connectivism and open educational resources movement. International Review of Research in Open and Distributed Learning, 16(5). 
Pearce, N., Weller, M., Scanlon, E. \& Kinsley, S. (2010). Digital scholarship considered: How new technologies could transform academic work. Education, 16(1).

Poikola, A., Kuikkaniemi, K., \& Honko, H. (2014). MyData a Nordic model for humancentered personal data management and processing. Helsinki: Finnish Ministry of Transport and Communication.

Recker, M., Yuan, M., \& Ye, L. (2014). Crowdteaching: Supporting teaching as designing in collective intelligence communities. International Review of Research in Open and Distributed Learning, 15(4).

Reynolds, R. (2015). Eight qualities of open pedagogies. Retrieved Oct 9, 2019 from https:// nextthought.com/thoughts/2015/02/ten-qualities-of-open-pedagogy.

Richardson, J., Milovidov, E., \& Schmalzried, M. (2017). Internet literacy handbook. Strasbourg: Council of Europe.

Rivoltella, P. C., \& Rossi, P. G. (Eds.). (2012). L'agire didattico. Brescia: Editrice La Scuola.

Rose, D. H., \& Meyer, A. (2007). Teaching Every student in the digital age: Universal design for learning. Education Technology Research and Development, 55, 521-525.

Ross, J., Sinclair, C., Knox, J., Bayne, S., \& Macleod, H. (2014). Teacher experiences and academic identity: The missing components of MOOC pedagogy. Journal of Online Learning and Teaching, 10(1), 57-69.

Ruys, I., Van Keer, H., \& Aelterman, A. (2011). Student teachers' skills in the implementation of collaborative learning: A multilevel approach. Teaching and Teacher Education, 27, 1090-1100.

Schleicher, A. (2014). Equity, excellence and inclusiveness in education: Policy lessons from around the world. In International summit on the teaching profession. Paris: OECD.

Siemens, G. (2004). Connectivism: A learning theory for the digital age. International Journal of Instructional Technology and Distance Learning, 2(1), 3-10.

Slade, S., \& Prinsloo, P. (2013). Learning analytics: Ethical issues and dilemmas. American Behavioral Scientist, 57(10), 1510-1529.

Sledge, L., \& Dovey Fishman, T. (2014). Reimagining higher education. Westlake: Deloitte University Press.

Stacey, P. (2013). The pedagogy of MOOCs. Retrieved Oct 9, 2019 from http://edtechfrontier.com/ 2013/05/11/the-pedagogy-of-moocs.

Tour, E. (2017). Teachers' self-initiated professional learning through personal learning networks. Technology, Pedagogy and Education, 26(2), 17-192.

Trinchero, R. (2018). Against the cognitive war. Promoting active skepticism. Media Education. 9(1), 17-36.

UNESCO. (2008). Teacher training curricula for media and information literacy. In Report of the International Expert Group Meeting. Paris: UNESCO.

Van Leeuwen, A., Janssen, J., Erkens, G., \& Brekelmans, M. (2013). Multidimensional teacher behavior in CSCL. In N. Rummel, M. Kapur, M. Nathan \& S. Puntambekar (Eds.), To see the world and a grain of sand: Learning across levels of space, time, and scale: CSCL 2013 Conference Proceedings, International Society of the Learning Sciences.

Villar, D. (2019). Celebrating the open web as a route towards a (more) critical digital education. Retrieved Oct 9, 2019 from https://education.okfn.org/celebrating-the-open-web-as-a-routetowards-a-more-critical-digital-education/.

Ward, D. (2017). Turning open education into a social movement. Centre for Teaching and Excellence blog: University of Kansas.

Weller, M. (2012). The digital scholar. London: Bloomsbury Academic.

Weller, M. (2014). The battle for open. London: Ubiquity Press.

Williams, R., Karousou, R. \& Mackness, J. (2011). Emergent learning and learning ecologies in Web 2.0. International Review of Research in Open and Distance Learning. 12(3). 
Fabio Nascimbeni works as Assistant Professor at the Universidad Internacional de la Rioja (UNIR), where he holds the Telefonica Chair on Digital Society and Education. He is a Senior Fellow of the European Distance and eLearning Network (EDEN), a member of the Advisory Board of the Open Education Working of the Open Knowledge Foundation, a fellow at the Centro de Estudos sobre Tecnologia e Sociedade of the University of Sao Paulo (USP) in Brazil and the Nexa Centre of the Politecnico di Torino. He has been active in the field of learning innovation and ICT for learning since 1998, by designing and coordinating more than 40 research and innovation projects and promoting European and international collaboration in different areas, from school education to higher education, to lifelong learning, to ICT research. He has been working across Europe as well as in Latin America, the Caribbean, the South Mediterranean and Southeast Asia. His main research interests are open education, learning innovation, digital literacy, social and digital inclusion.

Open Access This chapter is licensed under the terms of the Creative Commons Attribution 4.0 International License (http://creativecommons.org/licenses/by/4.0/), which permits use, sharing, adaptation, distribution and reproduction in any medium or format, as long as you give appropriate credit to the original author(s) and the source, provide a link to the Creative Commons license and indicate if changes were made.

The images or other third party material in this chapter are included in the chapter's Creative Commons license, unless indicated otherwise in a credit line to the material. If material is not included in the chapter's Creative Commons license and your intended use is not permitted by statutory regulation or exceeds the permitted use, you will need to obtain permission directly from the copyright holder.

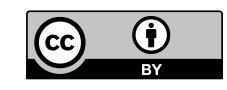

